DOI: 10.14807/ijmp.v12i3.1523

\title{
MANAGEMENT REPORT AS A COMPONENT OF NONFINANCIAL REPORTING IN UKRAINE: THEORY AND PRACTICE OF DRAFTING
}

\author{
Olena Petryk \\ Kyiv National Economic University named after Vadim Hetman, Ukraine \\ E-mail: auditlena@ukr.net \\ Alla Basok \\ Kyiv National Economic University named after Vadim Hetman, \\ Ukraine \\ E-mail: basok.alla@kneu.edu.ua
}

Tetiana Marenych

Kharkiv Petro Vasylenko National Technical University of Agriculture,

Ukraine

E-mail: thmarenych2020@gmail.com

Natalia Yatsenko

Kremenchuk National Mykhaylo Ostrogradskiy University, Ukraine E-mail:2015romanyatsenko@gmail.com

Sergey Kalinichenko Kharkiv Petro Vasilenko National Technical University of Agriculture,

Ukraine

E-mail: kalinichenkosergiy@gmail.com

Submission: $12 / 17 / 2020$

Revision: $1 / 5 / 2021$

Accept: 2/8/2021

\section{ABSTRACT}

The article covers the issue of compiling the Management Report. The need to implement a management report in Ukraine is caused by the processes of implementation of the European Union legislation on accounting in the national regulatory framework. The purpose of this report is to complement the annual financial statements with the necessary information, which should contain a reliable overview of development, activities and condition, as well as a description of the main risks and uncertainties in the work of an enterprise. This paper reviews the legislative framework for the preparation and publication of the Management Report and analyzes the Management Reports of domestic enterprises for compliance with regulatory requirements and the quality of these indicators. 
It has been defined that the lack of common normatively approved qualitative issues of the report and requirements for it are the significant problems. The format, scope, structure and accuracy of the information are determined at the discretion of an enterprise. The contained performance measures of enterprises significantly differ from each other and are not always given in comparison with the similar measures for the previous periods. Such presentation of data causes poor and uninformative reports. The results of the study prove that the Management Report should be based on the following principles: reliability and completeness, materiality, conciseness, integrity and comprehensibility; comparability of indicators. It is necessary to apply a risk-oriented approach and adhere the logic of presenting information with the elements of its visualization for its preparation. The study is based on the requirements of Directives 2013/34 / EU and 2014/95 / EU, the Law of Ukraine On Accounting and Financial Reporting in Ukraine, Methodological recommendations for the preparation of a management report, as well as empirical data obtained in the analysis of reports on management of Ukrainian enterprises.

Keywords: Management report; Non-financial reporting; Corporate social responsibility; Disclosure of nonfinancial information; Financial Information, Implementation of the EU Legislation.

\section{INTRODUCTION}

Corporate social responsibility and resistance are assuming a greater importance nowadays as the strategic factors of survival and attainment of longduration competitiveness on the market (Truant, Corazza \& Scagnelli, 2017). For that reason, the nonfinancial reporting and disclosure are becoming increasingly important (Stolowy \& Paugam, 2018).

For many years the European Union and the United Nations Organization have been moving towards sustainability and although the question of the social and environmental disclosure has been on the EU's agenda over the period of the past 20 years (Carini et al., 2018), regulatory action on nonfinancial disclosure has taken place recently in Europe with the implementation of Directive 2013/34/EU of the European Parliament on the annual financial statements, consolidated financial statements and related reports of certain types of undertakings (2013) and Directive 2014/95/EU on disclosure of non-financial and diversity 
DOI: 10.14807/ijmp.v12i3.1523

information by certain large undertakings and groups (2014) which emends the Directive 2013/34/EU.

The document requires large enterprises to publish nonfinancial information, including social and environmental issues. In other words, it's an attempt to move towards the harmonization of nonfinancial reporting (Aureli, Salvatori \& Magnaghi, 2020). Mandatory disclosure is necessary because the voluntary corporate social responsibility reporting (CSR) creates significant space for the 'symbolic' reports (Stittle, 2002).

Torre et al. (2018) claims that the directive is an act of policy to legitimize nonfinancial reporting which encompasses two major theories: the theory of improving the comparability of information and the theory of strengthening of corporate responsibility.

The interest in corporate disclosure of 'nonfinancial information' is increasing with the help of Directive 2014/95/EU. However, there is no generally accepted definition of this term. Prior to the EU directive it often meant the information about society and the environment, although a majority of scholars define and understand it differently - as a matter of corporate social responsibility, information about intellectual capital (Tarquinio \& Posadas, 2020).

The implementation of the EU Directive has crucial importance for improving of nonfinancial disclosure, as Francesca Manes-Rossi claims (2018). Disclosure of nonfinancial information, risk management and sustainability issues improves the firm valuation processes and has a positive impact on market price and equity cost of capital (Michelon, Pilonato \& Ricceri, 2015; Krištofík, Lament \& Musa, 2016).

However, Aureli, Salvatori and Magnaghi (2020) notes that states are characterized by different levels of understanding and experience of corporate social responsibility due to the fact that different national laws of corporate social responsibility reporting had appeared before the implementation of the Directive and have different levels of compliance with new legislation requirements (Venturelli et al., 2019). In particular, analyzing the nonfinancial information, disclosed in mandatory and voluntary reports of 223 large companies that are considered as the subjects of public interest for 2015, the average level of compliance was determined (Venturelli et al., 2017).

And in the case of Polish companies (Dyduch \& Krasodomska, 2017), to examine the level of nonfinancial disclosure, required by the Directive, 60 annual reports were explored. It was revealed that more than half of companies do not disclose any environmental information in their annual reports. 
DOI: 10.14807/ijmp.v12i3.1523

Consequently, as Popescu (2019) emphasises equitably, it is necessary to strengthen a corporate governance and a corporate social responsibility with the purpose of creating the appropriate balance between sustainability, competitiveness, productivity, financial and nonfinancial measures of business, taking into consideration the financial and intangible (eg. brand name, consumers' experience, intellectual capital, organizational culture and reputation) benefits.

In Ukraine the problem of preparation of nonfinancial reporting and the Management Report, which appeared as a result the directive implementation, is quite new. Therefore, the issues of structure, content and principles of preparation of the Management Report are underexplored by domestic scientists. However, some elements of the management report problematics were examined in the works of Ukrainian scientists.

Bezverkhyi and Pantelejev (2018) and Bondar (2017) made an in-depth study of the report structure, its content and compared with foreign counterparts.

Ozeran (2017) pointed to terminological inconsistencies between domestic legislative acts (specifically between the Law of Ukraine On Accounting and Financial Reporting in Ukraine, which provides for the preparation of a management report, and the Law of Ukraine On Securities and Stock Market), according to which a management report should be prepared as part of the annual and interim information about the securities issuer. It can be regarded as an interpretation of the same report, which should reflect the management opinion about the state and the development of an enterprise.

Lovinska and Oliinyk (2018) explored the regulation of nonfinancial reporting in Ukraine, particularly the management report. Also there is no consensus among scholars about the type of the report.

Onyshchenko (2018) claims that the management report is not an accounting one, unlike Ozeran (2017) who considers it as a component of the financial reporting.

\section{RESEARCH PROBLEM}

The necessity of a management report implementation in Ukraine is caused by the processes of introduction of European Union legislation on accounting in the national regulatory framework.

The Verkhovna Rada, the unicameral parliament of Ukraine, implementing the provisions of Directive 2013/34/EU of the European Parliament on the annual financial 
DOI: 10.14807/ijmp.v12i3.1523

statements, consolidated financial statements and related reports of certain types of undertakings and Directive 2014/95/EU, which amends Directive 2013/34/EU on disclosure of non-financial and diversity information by certain large undertakings and groups, established the concept and the purpose of preparing a management report in the Law of Ukraine On Amendment of the Law of Ukraine On Accounting and Financial Reporting in Ukraine to improve certain provisions of 05 October 2017 № 2164-VIII.

Such report is prepared in any form but the Order of the Ministry of Finance of Ukraine of 07 December 2018 № 982 On approval of the Methodological recommendations for the management report to ensure the comparability of the report approved the main content of the information that a company should display (Table 1).

The information requirements in the Management Report for the banks are also reflected in the instruction On the procedure for compiling and publishing of financial statements of banks of Ukraine, approved by the National Bank of Ukraine Resolution of 24 October 2011 №373 with the conforming amendments of 01 January 2019 (Table 1).

Table 1: Format for the information displaying in the Management Report according to the approved recommendations and instructions

\begin{tabular}{|c|c|c|}
\hline \multicolumn{3}{|c|}{ Management report } \\
\hline Reporter & Large and medium-sized businesses & Banks \\
\hline 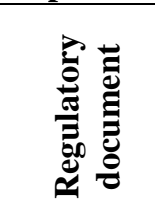 & $\begin{array}{c}\text { Methodical recommendations for compiling a } \\
\text { management report, affirmed by the order of } \\
\text { the Ministry of Finance of Ukraine } 07 \\
\text { December 2018 № 982. Amended } 18 \text { January } \\
2019\end{array}$ & $\begin{array}{l}\text { Instruction on the procedure of compiling and } \\
\text { publishing of financial statements of } \\
\text { Ukrainian banks. Affirmed by the National } \\
\text { Bank of Ukraine Resolution } 24 \text { October } 2011 \\
\text { №373. Amended 01 January } 2019\end{array}$ \\
\hline \multirow{10}{*}{ 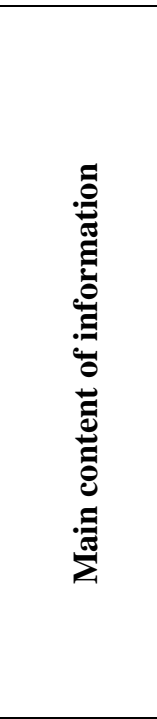 } & $\begin{array}{l}\text { Organisational set-up and a description of } \\
\text { activities of an enterprise }\end{array}$ & $\begin{array}{l}\text { Nature of the business (description of the } \\
\text { external environment bank operates in) }\end{array}$ \\
\hline & Operating results & $\begin{array}{c}\text { Management goals and strategies to achieve } \\
\text { these goals }\end{array}$ \\
\hline & Liquidity and liabilities & Resources, risks and relations \\
\hline & environmental aspects & $\begin{array}{l}\text { activity results and prospects of the further } \\
\text { development }\end{array}$ \\
\hline & social aspects and personnel policy & key performance indicators \\
\hline & risks & \\
\hline & research and innovation & \\
\hline & financial investments & \\
\hline & development prospects & \\
\hline & $\begin{array}{l}\text { corporate governance (consists of enterprises- } \\
\text { issuers, which securities are admitted to } \\
\text { trading on stock exchanges or in respect of } \\
\text { securities of which public offering has been } \\
\text { made) }\end{array}$ & \\
\hline
\end{tabular}

Source: "Methodical recommendations for compiling a management report" (2019), "Instruction on the procedure of compiling and publishing of financial statements of Ukrainian banks" (2019) 
According to paragraph 7 of article 11 of the Law of Ukraine On Accounting and Financial Reporting in Ukraine large and medium-sized businesses must prepare the management report and provide together with the financial statements.

So, as we see, there is a normative basis for the report formation, but the quantity of the questions about its methodology and organization of its preparation is not decreasing.

The practical recommendations for the preparation of the Management Report developed by LLC CRESTON GCG deserve attention. They are based on international experience and take into account the requirements of international and domestic legislation. According to these recommendations, the management report should contain the following sections (Table 2).

Table 2: LLC CRESTON GCG practical recommendations on the structure and content of the Management Report

\begin{tabular}{|c|c|c|}
\hline № & Section name & Characteristic \\
\hline 1 & $\begin{array}{l}\text { Reference of the } \\
\text { management }\end{array}$ & $\begin{array}{l}\text { This section is a 'preface' to the entire Report, in which the Company's senior } \\
\text { management refers to the users of the Report and in a narrative form informs its } \\
\text { users the most important, in their opinion, information that should set the tone } \\
\text { and the frames of perception of the Report. }\end{array}$ \\
\hline 2 & About a company & $\begin{array}{l}\text { General info. } \\
\text { Management and organizational structure. } \\
\text { Key indicators. } \\
\text { Main events and achievements of the reporting period }\end{array}$ \\
\hline 3 & $\begin{array}{l}\text { Strategy and business } \\
\text { model }\end{array}$ & $\begin{array}{l}\text { Mission, vision, values. } \\
\text { External opportunities and risks. } \\
\text { Strategy. Business model. } \\
\text { Development plans }\end{array}$ \\
\hline 4 & $\begin{array}{l}\text { Operation of the } \\
\text { company }\end{array}$ & $\begin{array}{l}\text { Product description. } \\
\text { Target and sales markets. } \\
\text { Production and technology. } \\
\text { Investment projects. } \\
\text { Financial review }\end{array}$ \\
\hline 5 & $\begin{array}{c}\text { Corporate } \\
\text { management }\end{array}$ & $\begin{array}{l}\text { Corporate governance structure. } \\
\text { Corporate governance policy }\end{array}$ \\
\hline 6 & $\begin{array}{l}\text { Sustainable } \\
\text { development }\end{array}$ & $\begin{array}{l}\text { Activities in the field of research and development. } \\
\text { Participation in global initiatives. } \\
\text { Protection of labour. } \\
\text { Environment preservation }\end{array}$ \\
\hline 7 & A company's risks & $\begin{array}{l}\text { Risk identification. } \\
\text { Risk management. }\end{array}$ \\
\hline 8 & $\begin{array}{l}\text { Financial } \\
\text { reporting }\end{array}$ & $\begin{array}{l}\text { Independent auditor's report. } \\
\text { Financial Statements. }\end{array}$ \\
\hline
\end{tabular}
Source: LLC CRESTON GCG practical recommendations (2018)

The proposed structure of the report is enough detailed and contains the vast majority of indicators that should be disclosed in the Management Report. Therefore, following the recommendations will help to prepare the Report as an integral and balanced document with the necessary information for users. 
According to the Law of Ukraine On Accounting and Financial Reporting in Ukraine the Management Report is a document that contains financial and nonfinancial information, which characterizes the state and the prospects of the development of an enterprise and discloses the main risks and uncertainties of its activities.

The purpose of this report is to supplement the annual financial statements with the necessary information, which should contain a reliable overview of development, activities and condition, as well as a description of the main risks and uncertainties in the work of an enterprise.

Considering the legal and practical provisions for the preparation of the management report, in order to identify the positive sides and problematic aspects it is advisable to analyze the reports of the specific enterprises.

The reports of Ukrainian pharmaceutical companies, that were available free, were selected to assess the practice of preparing the Management Reports, as this industry is important not only for economic but also for social and even political aspects of Ukrainian society. The published reports are analyzed for compliance with the help of the methodological recommendations for the preparation and the quality of information disclosure. (Table 3).

Table 3: Analysis of the reports on enterprises management of the pharmaceutical industry of Ukraine

\begin{tabular}{|c|c|c|c|c|}
\hline $\begin{array}{l}\text { Directions of } \\
\text { assessment }\end{array}$ & Criteria & $\begin{array}{c}\text { PrAT } \\
\text { Fitofarm }\end{array}$ & $\begin{array}{c}\text { PAT } \\
\text { Kyivmed- } \\
\text { preparat }\end{array}$ & $\begin{array}{l}\text { AT Halych- } \\
\text { farm }\end{array}$ \\
\hline \multirow{2}{*}{ Reporting form } & Special management report & + & + & + \\
\hline & Within the annual statement & - & - & - \\
\hline \multirow{6}{*}{$\begin{array}{l}\text { Compliance with } \\
\text { regulatory } \\
\text { requirements of the } \\
\text { Methodological } \\
\text { recommendations of } \\
\text { the Ministry of } \\
\text { Finance of Ukraine }\end{array}$} & Ecological aspects & + & + & + \\
\hline & Social aspects and personnel policy & + & + & $+/-$ \\
\hline & Risks & + & + & $+/-$ \\
\hline & $\begin{array}{l}\text { Specificity of disclosure of development } \\
\text { prospects }\end{array}$ & + & $+/-$ & $+/-$ \\
\hline & Comparability of performance & + & $+/-$ & + \\
\hline & $\begin{array}{l}\text { Comparability of liquidity data and } \\
\text { liabilities }\end{array}$ & $+/-$ & $+/-$ & + \\
\hline \multirow{3}{*}{$\begin{array}{c}\text { Disclosure of } \\
\text { information criteria } \\
\text { in the report }\end{array}$} & Quality and accuracy of presentation & $+/-$ & - & $+/-$ \\
\hline & Informativeness of the report & + & $+/-$ & - \\
\hline & $\begin{array}{l}\text { Data visualization (tables, graphs, charts, } \\
\text { photos) }\end{array}$ & + & $+/-$ & + \\
\hline
\end{tabular}

Source: own generalization based on published statements

The studied companies applied almost the same approaches to the information presentation. During the preparation of the Report the companies followed the methodological recommendations on its structure. 
DOI: 10.14807/ijmp.v12i3.1523

Thus, the PrAT Fitofarm management report (2019) is the most readable and full of visual information. The report is set out on 58 pages. Contains the tables and explanations to them, performance indicators of the enterprise and ratings presented in comparison with the previous years. The ratios of liquidity and financial stability are also given in descriptive form but it worsens their comparability with the previous periods. In terms of environmental aspects the company described specific activities carried out during the year. However, the financial investments and the enterprise risks are described quite briefly.

The PAT Kyivmedpreparat report (2018) is set out on 22 pages. Generally, its structure is followed in accordance with the current methodological recommendations. However, analyzing this report, it is clear that it is made only to ensure compliance with requirements of the Law of Ukraine On Accounting and Financial Reporting in Ukraine, but not for investors and ordinary users.

In particular, section 2 'Performance' contains a significant set of tables with indicators for different periods, but there are no any comments or explanation. The description of liquidity and liabilities was limited by the general information, without specifying and describing the indicators, detailing the company's liabilities. Financial investments are shown only in one table without any explanation. Risks and prospects for the development of PAT Kyivmedpreparat were also limited by the general information about business rivals and legal instability in Ukraine. Summarizing the information mentioned above, we may conclude that this report, although compiled in accordance with the recommended structure, does not provide distinct and qualitative information about the activities of the enterprise.

The AT Halychpharm report (2018) is the smallest among the analyzed reports and is set on only 7 pages and has mostly the text structure, except for financial results, which are presented in the tabular form, but without proper interpretations for users of the Report. Personnel policy and risks are revealed in the same style (the text form and a lack of specification of indicators). The positive features include the calculation of liquidity ratios and the disclosure of actual data on liabilities, which is important, in particular, for investors.

In the research process of management reports it is also important to analyze their content in terms of individual indicators.

Thus, the company PrAT Fitofarm (Table 4) provided a considerable list of indicators that allow users to assess its performance and financial condition, including indicators of income and liquidity. The information mentioned above confirms the conclusion about the 
INDEPENDENT JOURNAL OF MANAGEMENT \& PRODUCTION (IJM\&P)

http://www.ijmp.jor.br

v. 12, n. 3, Special Edition ISE, S\&P - May 2021

ISSN: 2236-269X

DOI: 10.14807/ijmp.v12i3.1523

formation of positive trends in the growth of liquidity, financial investment, staff rates and salaries.

Table 4: PrAT Fitofarm performance indicators

\begin{tabular}{|c|c|c|c|}
\hline \multirow{2}{*}{ Indicators } & \multicolumn{3}{|c|}{ PrAT Fitofarm } \\
\hline & 2019 & 2018 & Deviation \\
\hline \multicolumn{4}{|c|}{ Financial results of activity } \\
\hline $\begin{array}{l}\text { Production volume at wholesale prices, thousands } \\
\text { of UAH }\end{array}$ & 542882,30 & 570386,70 & 95 \\
\hline $\begin{array}{c}\text { Net revenue from product sales (goods, works, } \\
\text { services), thousands of UAH }\end{array}$ & 421332,20 & 464579,00 & 91 \\
\hline Gross income, thousands of UAH & 250443 & 285362 & 12 \\
\hline Share of exports in sales, $\%$ & 2 & 2 & 0 \\
\hline Financial leverage ratio (capital structure) & 0,74 & 0,73 & 0,01 \\
\hline \multicolumn{4}{|c|}{ Indicators of financial condition } \\
\hline Total liquidity ratio (coverage ratio) & 2,02 & 1,7 & 0,32 \\
\hline Rapid liquidity ratio & 1,38 & 1,28 & 0,1 \\
\hline Financial stability (or independence) ratio & 0,42 & 0,38 & 0,04 \\
\hline Absolute liquidity ratio & 0,0025 & 0,001 & 0,0015 \\
\hline Financial stability ratio & 0,42 & 0,38 & 0,04 \\
\hline \multicolumn{4}{|c|}{ Other indicators } \\
\hline Financial investments, thousands of UAH & 4128 & - & - \\
\hline The average number of employees, persons & 430 & 452 & 95 \\
\hline One employee's average salary in a month, UAH & 7142,00 & 5965,30 & 120 \\
\hline
\end{tabular}

Source: PrAT Fitofarm management report

The section on the financial results of the PAT Kyivmedpreparat presents only data on hospital segments without any explanation. Assessing these indicators, we can conclude that the company took a good position in 2017 and in 2018. It also reflects the average wage which according to the report was $21.5 \%$ higher in comparison to the previous year.

The indicators of loss of working time are given. However, such indicators as profit, liquidity, financial stability are absent. So we can't fully assess the financial condition of the enterprise. Financial investments are presented in terms of data on enterprises which securities were purchased but without comparisons with the previous periods and generalizations, so it is difficult to assess such information.

The report of AT Halychfarm (Table 5) provides indicators of financial results. Analyzing them we can see a tendency to increase of almost all indicators in 2018 in comparison with 2017, but the company does not comment on the results of its performance. The report also contains liquidity ratios, which value is within the norm, except the absolute liquidity ratio. The normative value of absolute liquidity should exceed 0.2 , and in AT Halychfarm as well as in PAT Fitofarm it is much less. However, this indicator does not immediately lead to negative conclusions about the company's ability to repay its debts without delay. 
INDEPENDENT JOURNAL OF MANAGEMENT \& PRODUCTION (IJM\&P)

http://www.ijmp.jor.br

v. 12, n. 3, Special Edition ISE, S\&P - May 2021

ISSN: 2236-269X

DOI: 10.14807/ijmp.v12i3.1523

Table 5: AT Halychfarm performance indicators

\begin{tabular}{|c|c|c|c|}
\hline \multirow{2}{*}{ Indicators } & \multicolumn{3}{|c|}{ AT Halychfarm } \\
\cline { 2 - 3 } Indicators of financial and economic activity (thousands, UAH) & Deviation \\
\hline Total number of assets & 2072758 & 1809146 & 263612 \\
\hline Money supply & 218566 & 180054 & 38512 \\
\hline Tixed assets (at residual value) & 375353 & 347676 & 27677 \\
\hline Money and its equivalents & 1171200 & 945541 & 225659 \\
\hline Equined earnings (uncovered loss) & 9819 & 21316 & -11497 \\
\hline Registered (share / authorized) capital & 503274 & 452655 & 50619 \\
\hline Long-term liabilities and providings & 579874 & 529255 & 50619 \\
\hline Current liabilities and providings & 76600 & 76600 & 0 \\
\hline Net financial result: profit (loss) & 247742 & 257083 & -9341 \\
\hline The average annual number of shares (units) & 1245142 & 1022808 & 222334 \\
\hline Net profit (loss) per 1 share (UAH) & 53588 & 38515 & 15073 \\
\hline Indicators of financial condition & 8511120 & 8510178 & 942 \\
\hline Total liquidity ratio (coverage ratio) & 1,251 & 4,52576 & 1,77047 \\
\hline Rapid liquidity ratio & 0,949 & 1,286 & $-0,035$ \\
\hline Absolute liquidity ratio & 0,008 & 0,946 & 0,003 \\
\hline Financial investments, thousands of UAH & 278670,1 & 0,021 & $-0,013$ \\
\hline
\end{tabular}

Source: AT Halychfarm management report

It is unlikely that all the creditors of the company would present their claims to it at the same time. Investment information is also provided, but without comparisons with previous periods.

\section{DATA AND METHODOLOGY}

The results of the study are based on the analysis of regulatory documents, scientific literature and financial and economic data, financial and non-financial reports of enterprises. The following methods were used for the purposes of the article: systematization and comparative method - for analysis of requirements and best practices for the preparation of management reports; content analysis - to analyze the content of management reports of the surveyed enterprises; tabular method - to visualize the results of the study; critical analysis and abstract-logical method - for theoretical generalization, conclusions, and definition of principles underlying the management report.

\section{RESULTS AND DISCUSSIONS}

Summarizing the results of the study, it can be concluded that for domestic enterprises one of the main problems, associated with the preparation of the Management Report, is the lack of requirements for the information to be disclosed in the report. The Law of Ukraine On Accounting and Financial Reporting in Ukraine does not contain requirements and explanation 
DOI: 10.14807/ijmp.v12i3.1523

regarding the structure, content and format of the Report. It focuses on the fact that the company has to decide itself what information needs to be disclosed.

The question of the responsibility for its drafting is also an open issue, as it is not legally identified. This work is predominantly in reliance upon an accounting department.

Considering the fact that the purpose of this report is to afford users the financial and nonfinancial information about the company's activities, it is necessary to decide a point: how to display it properly and accessibly to users? According to Sonnerfeldt, Ling, and Pontoppidan, (2020), the corporate reporting's role, function and limitations to strengthen its role as an agent of change, must be well understood by managers, regulators, corporations and their stakeholders.

All analyzed enterprises disclosed the information on their financial condition and activities. However, the contained indicators significantly differ and are not always given in comparison with the similar indicators of previous periods. Such presentation of data significantly impairs the analytical and informative reports, their comparability with other companies. Also the reports do not contain explanations and additional interpretations for most indicators, so users have to interpret the results themselves.

In our opinion, such information should be presented in the form of analytical data with comparability with the data of the previous reporting period; the dynamics of changes, deviations in the achievement of goals should also be reflected. Any tendencies should be described in detail. It will allow users to understand the real picture of the enterprise's activity. Information should not be only in numbers, it is necessary to add its visualization: graphics, infographics, illustrations, photos. Even the colors used are important, because they are methods of managing the user's impression. As Garcia-Sanchez emphasizes (2019), even the colours are important, because they are the methods of managing the user's impression. It is necessary to describe all the information in a perceptible style to ensure the clarity of the company's results for both specialists and a wide range of users.

In the analyzed reports we can see that the company's management is reluctant to disclose the information about the development strategy, financial results for the specific products and services, pricing policy, research and innovation, prospects for the further development of the company taking into account risks and challenges, referring to market competition and commercial confidentiality. This is because the management accounting information is known as the commercial confidentiality. Carini research (2018) is also 
ISSN: $2236-269 X$

DOI: 10.14807/ijmp.v12i3.1523

confirmed that information on environmental impact and issues, related to workers, social rights and human rights, risks and KPIs against corruption and bribery are still disclosed enough in the reports.

Currently, in Ukraine only large domestic enterprises and foreign companies disclose such data and are ready for even more detailed reporting (Table 6). An integral part of management in such companies is the corporate social responsibility, which involves openness and accountability to society.

Table 6: Examples of the best nonfinancial reports

\begin{tabular}{|c|c|c|c|}
\hline Company & Report title & Reference link to report & Characteristics \\
\hline Ukrtelecom & $\begin{array}{l}\text { Company } \\
\text { management } \\
\text { report }\end{array}$ & $\begin{array}{c}\text { https://ukrtelecom.ua/about/accounting/ } \\
\text { zviti-pro- } \\
\text { upravlinnya/docs/\%D0\%97\%D0\%B2 } \\
\% \text { D1\%96\%D1\%82\%20\%D0\%B7\%20 } \\
\% \text { D1\%83\%D0\%BF\%D1\%80\%D0\%B } \\
\text { 0\%D0\%B2\%D0\%BB\%D1\%96\%D0\% } \\
\text { BD\%D0\%BD\%D1\%8F\%202018\%20( } \\
\text { \%D1\%83\%D0\%BA\%D1\%80).pdf }\end{array}$ & $\begin{array}{l}\text { Contains the performance } \\
\text { results, strategic directions, } \\
\text { description of corporate } \\
\text { governance }\end{array}$ \\
\hline Energoatom & $\begin{array}{l}\text { Management } \\
\text { report }\end{array}$ & $\begin{array}{l}\text { http://www.energoatom.com.ua/upload } \\
\text { s/2020/web_EA_19_s.pdf }\end{array}$ & $\begin{array}{l}\text { Contains the information in } \\
\text { accordance with the legislative } \\
\text { requirements }\end{array}$ \\
\hline Oschadbank & $\begin{array}{l}\text { Annual report } \\
\text { (2018) }\end{array}$ & $\begin{array}{c}\text { https://old.bank.gov.ua/doccatalog/doc } \\
\text { ument?id=93985600 }\end{array}$ & $\begin{array}{l}\text { An example of a qualitative } \\
\text { annual report of the bank }\end{array}$ \\
\hline BASF & $\begin{array}{l}\text { Management's } \\
\text { Report (2018) }\end{array}$ & $\begin{array}{l}\text { https://report.basf.com/2018/en/service } \\
\text { pages/downloads/files/management_re } \\
\text { port_basf_ar18.pdf }\end{array}$ & $\begin{array}{l}\text { The report contains the } \\
\text { information by segments and } \\
\text { by regions. Includes } \\
\text { information about work in the } \\
\text { company, trainings for } \\
\text { employees }\end{array}$ \\
\hline Coca-cola & $\begin{array}{c}\text { Integrated } \\
\text { annual report } \\
(2017) \\
\end{array}$ & $\begin{array}{c}\text { https://ua.coca- } \\
\text { colahellenic.com/media/2665/2017_int } \\
\text { egrated-annual-report.pdf }\end{array}$ & $\begin{array}{c}\text { Consolidated annual report } \\
\text { which includes a management } \\
\text { report }\end{array}$ \\
\hline
\end{tabular}

Source: indicated in the table

It should be noted that the selected Reports are not a set of dry figures and tables. They contain the references of the management, graphs, charts, photos and comments to them.

There are some research papers (Matuszak \& Różańska, 2017) in which it is confirmed that regulated disclosure leads to increasing in the market value of the company. Nonfinancial reporting allows companies to demonstrate that they are socially responsible. It is a powerful tool for improving communication with stakeholder groups by increasing the transparency and the accountability of nonfinancial information (Patten \& Zhao, 2019).

That is why the question of how companies should report remains opened.

Tsagas and Villiers (2020) fairly points out that a clear guidance for what and how to report nowadays is needed. A standardized and streamlined structure is necessary to focus 
DOI: 10.14807/ijmp.v12i3.1523

companies on something more specific, rather than giving them too much choice of what guidelines, frameworks or recommendations they can choose. There is a need for clearer and more specific definitions of key concepts, as well as a clarification of the rights of stakeholders in this area.

Also it is necessary to pay attention to the enterprise's sectors of activity (Caputo, et al., 2019) because they can have different effects on the economic, environmental and social spheres, and in this sense a set of general rules may be insufficient to disclose nonfinancial information.

In addition, it is necessary to pay attention to the enterprise's sectors of activity (Caputo et al., 2019) because they can have different effects on the economic, environmental and social spheres, and in this sense a set of general rules may be insufficient to disclose nonfinancial information.

To sum up, it should be noted that the organization of the preparation of the management report is regulated by a number of regulations, in which indicative structure and deadlines for submission of such kind of a report are provided. However, based on the data of the analysis, we can conclude that domestic enterprises still do not have the sufficient experience in compiling such kind of reports and do not fully understand its benefits for the enterprise.

\section{CONCLUSIONS}

The Management report is a new phenomenon in the practice of reporting in Ukraine, due to the adoption of amendments to the Law of Ukraine 'On Accounting and Financial Reporting in Ukraine'. Its inoculation will ensure the implementation of European legislation into Ukrainian practice of reporting by market participants. Ukraine is currently in the process of adapting to this type of reporting of domestic enterprises, and scientists try to deepen the methodological and organizational aspects of its formation.

Domestic entrepreneurs just begin to implement the preparation and publication of the report and are not fully aware of all the benefits of a well-prepared report.

The absence of regulatory qualitative characteristics of the report and the requirements for it is the significant problem. The format, scope, structure and accuracy of the information are determined at the discretion of the company that causes the appearance of low-quality and uninformative reports. 
DOI: 10.14807/ijmp.v12i3.1523

The management of the enterprise have to understand that, in fact, the Management Report is a business card of the enterprise, in particular for investors. That is why a qualitative analysis of the activities of any enterprise should be reflected in a perceptible format. Thus, the Management Report should be based on the following principles: reliability and completeness, materiality, brevity, integrity and comprehensibility; comparability of indicators. In its preparation it is necessary to apply a risk-oriented approach and follow the logic of presenting the information with the elements of its visualization.

\section{REFERENCES}

Aluchna, M., Hussain, N., \& Roszkowska-Menkes, M. (2019). Integrated Reporting Narratives: The Case of an Industry Leader. Sustainability, 11(4),976. DOI: 10.3390/su11040976.

Aureli, S., Salvatori, F., \& Magnaghi, E. (2020). A Country-Comparative Analysis of the Transposition of the EU Non-Financial Directive: An Institutional Approach. Accounting, Economics, and Law: A Convivium. Available:

https://www.degruyter.com/view/journals/ael/10/2/article-20180047.xml. Access: 8th October, 2020.

Bezverkhyj, K. V., \& Pantelejev, V. P. (2018). Konsolidovanyj zvit pro upravlinnja. Novaciji upravlinsjkoji praktyky zvituvannja. [Consolidated management report. Innovations in management reporting practices]. Scientific Bulletin of the National Academy of Statistics, Accounting and Auditing, (1-2), 37-46.

Bondar, T. A. (2017). Zvit pro upravlinnia: etapy skladannia. Suchasni tendentsii rozvytku obliku, opodatkuvannia, analizu i audytu [Management report: stages of compilation. Current trends in accounting, taxation, analysis and audit]. Kyiv: KNEU, 115-117.

Caputo, F., Leopizzi, R., Pizzi, S., \& Milone, V. (2019). The Non-Financial Reporting Harmonization in Europe: Evolutionary Pathways Related to the Transposition of the Directive 95/2014/EU within the Italian Context. MDPI and ACS Style, 12, 92. Available: https://www.mdpi.com/2071-1050/12/1/92/htm.

Carini, C., Rocca, L., Veneziani, M., \& Teodori, C. (2018). Impact Assessment of Sustainability Information-The Directive 2014/95. MDPI and ACS Style, 10, 560. Available: https://www.mdpi.com/2071-1050/10/2/560/.

Diadiun, O., Petryk, O., Semenyshena, N., Khorunzhak, N., \& Kalinichenko, S. (2020). Integrated Reporting in the Conditions of Sustainable Development: Institutionalization Through Standardization. Intellectual Economics, 14(2), 67-86. DOI: 10.13165/IE-20-14-205 .

Directive 2013/34/Eu Of The European Parliament And Of The Council of 26 June 2013. Available: https://eur-lex.europa. eu /legal-content /EN/TXT/HTML/?uri= CELEX:32013 L0034\&from=EN. Access: 5th October, 2020.

Directive 2014/95/Eu Of The European Parliament And Of The Council of 22 October 2014 of 22 October 2014. Available: https://eur-lex.europa.eu/legalcontent/EN/TXT/HTML/?uri=CELEX:32014 L0095\& from=EN. Access: 6th October, 2020. 
INDEPENDENT JOURNAL OF MANAGEMENT \& PRODUCTION (IJM\&P)

http://www.ijmp.jor.br

v. 12, n. 3, Special Edition ISE, S\&P - May 2021

ISSN: 2236-269X

DOI: 10.14807/ijmp.v12i3.1523

Dyduch, J., \& Krasodomska, J. (2017). Determinants of Corporate Social Responsibility Disclosure: An Empirical Study of Polish Listed Companies. MDPI and ACS Style, 9, 1934. Available: https://www.mdpi.com/2071-1050/9/11/1934. Access: 10th October, 2020.

Instruktsiia Pro Poriadok Skladannia Ta Opryliudnennia Finansovoi Zvitnosti Bankiv Ukrainy (2019). Instruction on the procedure for compiling and publishing of financial statements of Ukrainian banks. Approved by the National Bank of Ukraine Resolution of 24.10.2011 №373. In the edition of 01.01.2019]. Available:

https://zakon.rada.go,ua/laws/show/z1288-11\#Text. Access: 16th October, 2020.

García-Sánchez, I.-M., \& Araújo-Bernardo, C.-A. (2019). What colour is the corporate social responsibility report? Structural visual rhetoric, impression management strategies, and stakeholder engagement. Corporate Social Responsibility and Management, 27(2), 1117 1142. DOI: $10.1002 / \mathrm{csr} .1869$.

Krištofík, P., Lament, M., \& Musa, H. (2016). The reporting of non-financial information and the rationale for its standardisation. Ekonomika a management, 2, XIX. Available: https://dspace.tul.cz/bitstream/handle/ 15240/16437/EM_2_2016_11.pdf?sequence=2. Access: 5th October, 2020.

Lovinska L. H., Oliinyk Ya. V., \& Bondar, T. A. (2018). Normatyvno-pravove zabezpechennia zvitu pro upravlinnia pidpryiemstv v Ukraini [Regulatory and legal support of the report on enterprise management in Ukraine]. Finansy Ukrainy (electronic journal). (6), 19-44 Retrieved from: http://finukr.org.ua/docs/FU_18_06_019_uk.pdf. Access: 1th October, 2020.

Management Report of Prat Fitofarm (2019). Приватне Акціонерне Товариство "Фітофарм". Retrieved from: https://fitofarm.ua/wpcontent/uploads/2020/05/\%D0\%A4\%D0\%86\%D0\%A2\%D0\%9E\%D0\%A4\%D0\%90\%D0\% A0\%D0\%9C_12-\%D0\%BC\%D1\%96\%D1\%81-2019.-

$\% \mathrm{D} 0 \% 97 \% \mathrm{D} 0 \% \mathrm{~B} 2 \% \mathrm{D} 1 \% 96 \% \mathrm{D} 1 \% 82-\% \mathrm{D} 0 \% \mathrm{BF} \% \mathrm{D} 1 \% 80 \% \mathrm{D} 0 \% \mathrm{BE}-$

$\% \mathrm{D} 1 \% 83 \% \mathrm{D} 0 \% \mathrm{BF} \% \mathrm{D} 1 \% 80 \% \mathrm{D} 0 \% \mathrm{~B} 0 \% \mathrm{D} 0 \% \mathrm{~B} 2 \% \mathrm{D} 0 \% \mathrm{BB} \% \mathrm{D} 1 \% 96 \% \mathrm{D} 0 \% \mathrm{BD} \% \mathrm{D} 0 \% \mathrm{BD} \%$ D1\%8F.pdf.

Management Report of at «Halychfarm» (2018). 3bit цро уцрабліннЯ ат «ГалнЧФарм». Available:

http://www.galychpharm.com/files/\%D0\%97\%D0\%B2\%D1\%96\%D1\%82\%20\%D0\%BF\%D $1 \% 80 \% \mathrm{D} 0 \% \mathrm{BE} \% 20 \% \mathrm{D} 1 \% 83 \% \mathrm{D} 0 \% \mathrm{BF} \% \mathrm{D} 1 \% 80 \% \mathrm{D} 0 \% \mathrm{~B} 0 \% \mathrm{D} 0 \% \mathrm{~B} 2 \% \mathrm{D} 0 \% \mathrm{BB} \% \mathrm{D} 1 \% 96 \%$ D0\%BD\%D0\%BD\%D1\%8F\%20\%D0\%B7\%D0\%B0\%202018\%D1\%80.pdf. Access: 1th October, 2020.

Management Report Of Pat «Kyivmedpreparat» (2018). Публічного Акціонерного товариства «Київмедпрепарат». Available:

http://www.kievmedpreparat.com/files/\%D0\%97\%D0\%B2\%D1\%96\%D1\%82\%20\%D0\%BF $\% \mathrm{D} 1 \% 80 \% \mathrm{D} 0 \% \mathrm{BE} \% 20 \% 20 \% 20 \% \mathrm{D} 1 \% 83 \% \mathrm{D} 0 \% \mathrm{BF} \% \mathrm{D} 1 \% 80 \% \mathrm{D} 0 \% \mathrm{~B} 0 \% \mathrm{D} 0 \% \mathrm{~B} 2 \% \mathrm{D} 0 \% \mathrm{~B}$ B\%D1\%96\%D0\%BD\%D0\%BD\%D1\%8F\%20\%D0\%B7\%D0\%B0\%202018\%D1\%80..pdf. Access: 1th October, 2020.

Management Report Of Prat «Fitofarm» (2019). Приватне Акціонерне Товариство "Фітофарм". Available: https://fitofarm.ua/wpcontent/uploads/2020/05/\%D0\%A4\%D0\%86\%D0\%A2\%D0\%9E\%D0\%A4\%D0\%90\%D0\% A0\%D0\%9C_12-\%D0\%BC\%D1\%96\%D1\%81-2019.-

$\% \mathrm{D} 0 \% 97 \% \mathrm{D} 0 \% \mathrm{~B} 2 \% \mathrm{D} 1 \% 96 \% \mathrm{D} 1 \% 82-\% \mathrm{D} 0 \% \mathrm{BF} \% \mathrm{D} 1 \% 80 \% \mathrm{D} 0 \% \mathrm{BE}-$

$\% \mathrm{D} 1 \% 83 \% \mathrm{D} 0 \% \mathrm{BF} \% \mathrm{D} 1 \% 80 \% \mathrm{D} 0 \% \mathrm{~B} 0 \% \mathrm{D} 0 \% \mathrm{~B} 2 \% \mathrm{D} 0 \% \mathrm{BB} \% \mathrm{D} 1 \% 96 \% \mathrm{D} 0 \% \mathrm{BD} \% \mathrm{D} 0 \% \mathrm{BD} \%$ D1\%8F.pdf. Access: 1th October, 2020. 
Manes-Rossi, F., Tiron-Tudor, A., Nicolò, G., \& Zanellato, G. (2018). Ensuring More Sustainable Reporting in Europe Using Non-Financial Disclosure-De Facto and De Jure Evidence. MDPI and ACS Style, 10, 1162. Available: https://www.mdpi.com/20711050/10/4/1162/htm\#B6-sustainability-10-01162. Access: 2th October, 2020.

Matuszak, Ł., \& Różańska, E. (2017). CSR Disclosure in Polish-Listed Companies in the Light of Directive 2014/95/EU Requirements: Empirical Evidence. MDPI and ACS Style, 9, 2304. Available: https://www.mdpi.com/2071-1050/9/12/2304. Access: 3th October, 2020.

Metodychni Rekomendatsii Z Pidhotovky Zvitu Pro Upravlinnia (2018). KRESTON GCG [Guidelines for the preparation of the Management Report (2018). Kreston GCG]. Available: https://kreston-gcg.com/wp-content/uploads/2018/11/15-11-

2018_report_cover_fin-pdf-pdf.pdf. Access; 4th October, 2020.

Michelon, G., Pilonato, S., \& Ricceri, F. (2015). CSR reporting practices and the quality of disclosure: An empirical analysis. Critical Perspectives on Accounting, 33, 59-78. Available: https://www.sciencedirect.com/science/article/abs/pii/ S1045235414001 051?via\%3Dihub. Access 6th October, 2020.

Ministry Of Finance (2019). Methodical recommendations for compiling a management report, approved by the order of the Ministry of Finance dated 07.12.2018 № 982. As amended on 18.01.2019. Retrieved from: https://zakon.rada.go,ua/rada/show/v098220118\#Text . Access 1th October, 2020.

National Bank Of Ukraine (2011). Instruction on the procedure for compiling and publishing of financial statements of Ukrainian banks. Approved by the National Bank of Ukraine Resolution of 24.10.2011 №373. In the edition of 01.01.2019. Retrieved from: https://zakon.rada.go,ua/laws/show/z1288-11\#Text . Access 1th October, 2020.

Official Journal Of The European Union (2013). Directive 2013/34/EU of the European Parliament and of the Council of 26 June 2013. Available: https://eur-lex.europa.eu/legalcontent/EN/TXT/?uri=celex\%3A32013L0034_Access 1th October, 2020.

Official Journal Of The European Union (2014). Directive 2014/95/EU of the European Parliament and of the Council of 22 October 2014. Available: https://eurlex.europa.eu/legal-content/EN/TXT/?uri=CELEX\%3A32014L0095. Access: 1th October, 2020.

Onyshchenko, V. (2018). Porivniannia natsionalnykh ta mizhnarodnykh vymoh do skladannia zvitu pro upravlinnia [Comparison of national and international management reporting requirements]. Problems and prospects of economics and management, 16(4), 230-238.

Ozeran, A. V. (2017). Zvit kerivnytstva VS zvit pro upravlinnia: problemy vidpovidnosti zakonu pro bukhhalterskyi oblik ta svitovoi praktyky [Management Report Vs Management report: problems of compliance with accounting law and world practice]. Bukhhalterskyi oblik i audyt, (10-11), 2-12.

Patten, D. M., \& Zhao, N. (2014). Standalone CSR reporting by U.S. retail companies. Accounting Forum, 38(2), 132-144, DOI: 10.1016/j.accfor.2014.01.002.

Popescu, C. R. G. (2019). Corporate Social Responsibility, Corporate Governance and Business Performance: Limits and Challenges Imposed by the Implementation of Directive 2013/34/EU in Romania. MDPI and ACS Style, 11, 5146. Available: https://www.mdpi.com/2071-1050/11/19/5146/htm. Access: 3th October, 2020. 
Semenyshena, N., Khorunzhak, N., \& Zadorozhnyi, Z.-M. (2020). The Institutionalization of Accounting: the Impact of National Standards on the Development of Economies.

Independent Journal of Management \& Production, 11(8), 695-711.

DOI: $10.14807 /$ ijmp.v11i8.1228.

Semenyshena, N., Sysiuk, S., Shevchuk, K., Petruk, I., \& Benko, I. (2020). Institutionalism in Accounting: a Requirement of the Times or a Mechanism of Social Pressure? Independent Journal of Management \& Production, 11(9), 2516-2541. DOI: 10.14807/ijmp.v11i9.1440.

Sonnerfeldt, A., Ling, Li., \& Pontoppidan, C. A. (2020). The Challenges of Assurance on Non-financial Reporting. Accounting, Economics, and Law: a Convivium,10(2).

Stittle, J. (2002). UK Corporate Ethical Reporting - A Failure to Inform: Some Evidence from Company Annual Reports, Business and Society review, 107(3). DOI: 10.1111/14678594.00140 .

Stolowy, H., \& Paugam, L. (2018). The expansion of non-financial reporting: an exploratory study. Accounting and Business Research, 48(5), 525-548. DOI: 10.1080/00014788.2018.1470141.

Tarquinio, L., \& Posadas, S. C. (2020). Exploring the term "non-financial information": an academics' view. Meditari Accountancy Research, 28(5), 727-749. DOI: 10.1108/MEDAR-11-2019-0602.

Torre, M., Sabelfeld, S., Blomkvist, M., Tarquinio, L., \& Dumay, J. (2018)., Harmonising non-financial reporting regulation in Europe: Practical forces and projections for future research. Meditari Accountancy Research, 26(4), 598-621. DOI: 10.1108/MEDAR-022018-0290.

Truant, E., Corazza, L., \& Scagnelli, S. D. (2017). Sustainability and Risk Disclosure: An Exploratory Study on Sustainability Reports. MDPI and ACS Style, 9, 636. Available: https://www.mdpi.com/2071-1050/9/4/636. Access: 1th October, 2020.

Tsagas, G., \& Villiers, Ch. (2020). Why "Less is More” in Non-Financial Reporting Initiatives: Concrete Steps Towards Supporting Sustainability. Accounting, Economics, and Law: a Convivium, 10(2). Available: https://www.degruyter.com/view/journals/ael/aheadof-print/article-10.1515-ael-2018-0045/article-10.1515-ael-2018-0045.xml. Access: 7th October, 2020.

Venturelli, A., Caputo, F., Cosma, S., Leopizzi, R., \& Pizzi, S. (2017). Directive 2014/95/EU: Are Italian Companies Already Compliant? MDPI and ACS Style, 9, 1385. Available: https://www.mdpi.com/2071-1050/9/8/1385. Access: 1th October, 2020.

Venturelli, A., Caputo, F., Leopizzi, R., \& Pizzi, S. (2019). The state of art of corporate social disclosure before the introduction of non-financial reporting directive: a cross country analysis, Social Responsibility Journal, 15(4), 409-423. DOI: 10.1108/SRJ-12-2017-0275. 